\title{
STUDIES ON COPPER METABOLISM. XIV. COPPER, CERULO- PLASMIN AND OXIDASE ACTIVITY IN SERA OF NORMAL HUMAN SUBJECTS, PREGNANT WOMEN, AND PA- TIENTS WITH INFECTION, HEPATOLENTICULAR DEGENERATION AND THE NEPHROTIC SYNDROME ${ }^{1}$
}

\author{
By H. MARKOWITZ, C. J. GUBLER, J. P. MAHONEY,2 G. E. CARTWRIGHT, AND \\ M. M. WINTROBE \\ (From the Department of Medicine, University of Utah, College of Medicine, Salt Lake City, \\ Utah)
}

(Submitted for publication February 25, 1955 ; accepted June 8, 1955)

Ceruloplasmin, the blue copper-containing protein of serum, was first isolated in 1948 by Holmberg and Laurell (1). They characterized this protein as an alpha 2 globulin with a copper content of approximately 0.32 per cent, ${ }^{3}$ a molecular weight of about 151,000 and 8 atoms of copper per molecule. The substance has been shown to exhibit oxidase activity with a variety of substrates. The enzyme is most active with paraphenylene diamine $(2,3)$.

Holmberg and Laurell (4) observed that ceruloplasmin could be precipitated from normal human serum made 50 per cent saturated with ammonium sulfate. However, approximately 2 to 12 per cent of the total copper remained in the soluble "albumin" fraction. They suggested that the copper remaining in the albumin fraction might be attached to globulin which could not be completely separated from the albumin by ammonium sulfate precipitation. More recently, in our laboratory (5), it was demonstrated that there is a small fraction of the plasma copper ( 0 to 17 per cent) in normal subjects which reacts directly

1 This investigation was supported by a research grant (C-2231) from the National Cancer Institute, National Institutes of Health, Public Health Service.

2 Public Health Research Fellow of the National Heart Institute.

${ }^{8}$ If ceruloplasmin contains 8 atoms of copper per mole, the correct molecular weight for the observed copper concentration of 0.32 per cent would be 159,000 . The exact molecular weight of ceruloplasmin is uncertain. Holmberg and Laurell gave the figure as "approximately" 151,000 . However, if this is correct, the copper concentration should be 0.336 per cent. We have arbitrarily chosen 0.32 per cent for the purposes of the calculations in this paper, since this is the value which Holmberg and Laurell actually found. with the copper colorimetric reagent, sodium diethyldithiocarbamate. This fraction has been referred to as the "direct-reacting fraction" of plasma or serum copper and evidence has been brought forward that it is this fraction which is actively concerned in the transportation of copper. The remainder of the copper in plasma does not react directly with the carbamate reagent and has been referred to as the "indirect-reacting fraction" of plasma copper. This presumably corresponds to ceruloplasmin. Recently, Bearn and Kunkel (6), by the use of zone electrophoresis, have presented evidence that the direct-reacting copper is bound to serum albumin.

It has been demonstrated repeatedly that the total plasma copper level is elevated in the last trimester of pregnancy $(7,8)$ and in patients with infections (7-9). Holmberg and Laurell $(4,10)$ demonstrated that in such patients most of the copper is associated with the globulin fraction and that there is a high degree of correlation between the copper content of the sera and the oxidase activity. In pregnant women, the hypercupremia is due mainly to an increase in ceruloplasmin (11) ; although there is a modest increase in the direct-reacting fraction as well (5).

It is now known that hypocupremia is present in most patients with Wilson's disease $(8,12,13)$ and in some patients with the nephrotic syndrome (14). In Wilson's disease it has been demonstrated that there is a marked decrease in the indirect-reacting fraction of plasma copper and an increase in the direct-reacting fraction (13). Scheinberg and Gitlin (15), by the use of specific immunologic techniques, measured ceruloplasmin directly and found it to be markedly reduced. In 
the nephrotic syndrome (14), it has been suggested that the hypocupremia is the consequence of the loss of ceruloplasmin in the urine. Although patients with the nephrotic syndrome have been found to excrete increased quantities of copper in the urine, it has not been demonstrated conclusively that the copper is excreted as ceruloplasmin.

The purpose of this paper is to present the results of measurements of total serum copper, direct-reacting copper, indirect-reacting copper, ceruloplasmin and oxidase activity in the sera of normal human subjects, pregnant women, and patients with infection, Wilson's disease, the nephrotic syndrome, and miscellaneous conditions. We have also measured the ceruloplasmin concentration in the urine of patients with Wilson's disease and the nephrotic syndrome and in several tissues of one patient with Wilson's disease and of two subjects without Wilson's disease.

\section{METHODS}

The patients used in this study, in most instances, were not hospitalized. The pregnant women were all in the third trimester of an uncomplicated pregnancy. Five of the patients (Del. H., Dar. H., D. C., R. K., and J. S.) with Wilson's disease have been reported in a previous publication from this laboratory (13). Two additional cases (J. Si. and B. S.) have been studied in detail in this laboratory since the previous publication. The remainder of the sera from patients with Wilson's disease were kindly sent to us by various physicians.4 One of these patients ( $H$. C.) has been the subject of two reports $(16,17)$.

All but three of the patients with the nephrotic syndrome who were studied manifested the classical features of this condition; namely, intractable edema, massive proteinuria, lipemia and hypoalbuminemia. Four (C. E., C. S., H. B., and R. P.) were adults in whom the nephrosis was presumably secondary to chronic glomerulonephritis. Five ${ }^{5}$ (W. W., G. H., H. A., L. L.,

${ }^{4} \mathrm{We}$ are indebted to the following physicians for sending us specimens of serum and for granting us permission to publish the results of the analyses; Dr. R. E. Hodges, University of Iowa, Iowa City, Iowa (patients R. K., W. K., and J. S.) ; Dr. W. N. Jensen, Veterans Administration Hospital, Durham, N. C. (patient W. S.) ; Dr. J. G. Palmer, University of North Carolina, Chapel Hill, N. C. (patients N. P. and A. S.) ; Dr. C. G. Warnock, Royal Victoria Hospital, Belfast, Ireland (patients H. C. and P. C.) ; Dr. G. S. Ferriss, Charity Hospital of Louisiana, New Orleans, La. (patient F. D.).

5 We are indebted to Dr. Phillip Sturgeon, Children's Hospital Society, Los Angeles, Cal., for sending us sera from these patients. and S. C.) were children. In these the syndrome could be classified as the so-called "pure" or "lipoid nephrosis."

All analyses were performed on serum which had been collected carefully to prevent contamination with copper. Measurements of direct-reacting copper and oxidase activity were performed on fresh serum only.

The methods for the determination of total serum copper (5), the direct-reacting fraction of serum copper (5), urine copper (14), tissue copper (18), and urine protein (14) have been described in previous publications. The oxidase activity of the serum was estimated by the method of Holmberg and Laurell (2) employing paraphenylene diamine as a substrate.

Ceruloplasmin was measured immunologically by the use of rabbit anti-human ceruloplasmin serum which had been absorbed with serum from a patient with Wilson's disease (15). Rabbits were immunized by the Lipton and Freund adjuvant technique (19) with ceruloplasmin isolated in this laboratory (1) from human serum. The sample (C-V) used for immunization contained 0.23 per cent copper and 14.0 per cent nitrogen. Both intracutaneous and intramuscular routes were used simultaneously. Each rabbit received one injection of $4 \mathrm{mg}$. ceruloplasmin weekly for six weeks and was bled by cardiac puncture seven days after the last injection.

The pooled serum was absorbed twice with $0.5 \mathrm{ml}$. portions of serum from Del. $\mathrm{H}$. for 48 hours at 0 to $5^{\circ} \mathrm{C}$. and was then tested by the Oudin technique (20). A concentrated solution of ceruloplasmin $(5.25 \mathrm{mg}$. per ml.) in $0.15 \mathrm{M}$ saline, normal serum, and serum from a patient with Wilson's disease were used as antigens. $\mathrm{Ab}$ sorptions with $0.5 \mathrm{ml}$. portions of serum from Del. $\mathrm{H}$. were continued until only one zone was obtained.

The sera were calibrated with human ceruloplasmin. It was assumed that the copper concentration of pure ceruloplasmin is 0.32 per cent. The amount of antibody was estimated by a modification of the colorimetric method of Heidelberger and MacPherson $(21,22)$. One ml. of a 1:4 dilution of antiserum was chilled to $0^{\circ} \mathrm{C}$. and 1.0 to $3.0 \mathrm{ml}$. of the appropriately diluted test solution was added. The total volume was made up to 4.0 ml. with cold $0.15 \mathrm{M}$ saline and the tubes were kept at 0 to $5^{\circ} \mathrm{C}$. for four days and then centrifuged at 0 to $4^{\circ} \mathrm{C}$. The precipitate, after washing with $3.0 \mathrm{ml}$. and then 2.5 ml. of cold saline, was dissolved in three drops of N/10 sodium hydroxide and diluted to $2.5 \mathrm{ml}$. with water. The color was developed as outlined by Heidelberger and MacPherson. The densities of the solutions were measured in a Beckman Model B Spectrophotometer at a wave length of $650 \mathrm{~m} \mu$ and the concentration of ceruloplasmin was determined from the calibration curve. The supernatant solutions from the precipitin tests were checked for excess antibody. All determinations were run in the region of antibody excess since the calibration curve for the antiserum is valid only in this range.

Tissues for ceruloplasmin analysis were stored at $-30^{\circ}$ C. until used. Small samples (1 to $2 \mathrm{gm}$.) were homogenized in a Virtis homogenizer (Model 6-105) with $0.15 \mathrm{M}$ saline in the cold. The homogenates were centrifuged at 12,000 r.p.m. for 30 minutes. Cerulo- 
TABLE I

Normal human subjects

\begin{tabular}{|c|c|c|c|c|c|c|}
\hline Subject & Sex & $\begin{array}{c}\text { Total } \\
\text { serum } \\
\text { copper } \\
\mu \mathrm{g} / 100 \mathrm{ml} .\end{array}$ & $\begin{array}{c}\text { Direct- } \\
\text { reacting } \\
\text { copper } \\
\mu \mathrm{g} / 100 \mathrm{ml} .\end{array}$ & $\begin{array}{l}\text { Indirect- } \\
\text { reacting } \\
\text { copper } \\
\mu \mathrm{g} / 100 \mathrm{ml} \text {. }\end{array}$ & $\begin{array}{c}\text { Cerulo- } \\
\text { plasmin } \\
m g . / 100 ~ m l .\end{array}$ & $\begin{array}{c}\text { Oxidase } \\
\text { activity } \\
\mu M O_{2} / m b . / h r .\end{array}$ \\
\hline $\begin{array}{l}\text { H. M. } \\
\text { S. A. } \\
\text { A. S. } \\
\text { G. C. } \\
\text { J. M. } \\
\text { L. H. } \\
\text { M. Y. } \\
\text { G. T. } \\
\text { A. W. } \\
\text { N. B. }\end{array}$ & $\begin{array}{l}\mathbf{M} \\
\mathbf{M} \\
\mathbf{M} \\
\mathbf{M} \\
\mathbf{M} \\
\mathbf{F} \\
\mathbf{F} \\
\mathbf{F} \\
\mathbf{F} \\
\mathbf{F}\end{array}$ & $\begin{array}{r}92 \\
107 \\
101 \\
104 \\
114 \\
110 \\
116 \\
111 \\
123 \\
97\end{array}$ & $\begin{array}{r}0 \\
0 \\
0 \\
6 \\
0 \\
11 \\
6 \\
17 \\
0 \\
9\end{array}$ & $\begin{array}{r}92 \\
107 \\
101 \\
98 \\
114 \\
99 \\
110 \\
94 \\
123 \\
88\end{array}$ & $\begin{array}{l}27 \\
30 \\
33 \\
31 \\
38 \\
34 \\
38 \\
38 \\
38 \\
30\end{array}$ & $\begin{array}{l}4.3 \\
3.4 \\
3.5 \\
3.0 \\
4.7 \\
3.8 \\
4.8 \\
4.1 \\
4.7 \\
3.0\end{array}$ \\
\hline $\begin{array}{l}\text { Mean } \\
\text { 土S.D. } \\
\text { Range }\end{array}$ & & $\begin{array}{c}108 \\
\pm 9 \\
92-123\end{array}$ & $\begin{array}{l}5 \\
\pm 6 \\
0-17\end{array}$ & $\begin{array}{c}103 \\
\pm 11 \\
88-114\end{array}$ & $\begin{array}{c}34 \\
\pm 4 \\
27-38\end{array}$ & $\begin{array}{l}3.9 \\
\pm 0.7 \\
3.0-4.7\end{array}$ \\
\hline
\end{tabular}

plasmin was determined on aliquots of the supernatant solutions as outlined above. Tissue extracts were set up against normal rabbit serum to test for non-specific precipitation. These tests were negative. In order to correct for the ceruloplasmin contributed by the serum trapped in the tissues of the two control subjects, a hemoglobin determination was done on aliquots of the supernatant solutions.

\section{RESULTS}

\section{Normal human subjects}

The data for 10 normal subjects are presented in Table $I$. The mean value for total serum copper of $108 \mu \mathrm{g} /$ per $100 \mathrm{ml}$. corresponds well with the normal mean determined previously in this laboratory in a much larger group (14). Likewise, the mean value for the direct-reacting frac- tion of $5 \mu \mathrm{g}$ per $100 \mathrm{ml}$. corresponds well with the mean values of 4 and $8 \mu \mathrm{g}$ per $100 \mathrm{ml}$., respectively, previously reported $(5,13)$.

The mean value for ceruloplasmin concentration was $34 \mathrm{mg}$. per $100 \mathrm{ml}$. and for oxidase activity, $3.9 \mu \mathrm{M} \mathrm{O}_{2}$ per $\mathrm{ml}$. per $\mathrm{hr}$.

Assuming that ceruloplasmin contains 0.32 per cent copper (1), the amount of copper accounted for in the ceruloplasmin is $109 \mu \mathrm{g}$ per $100 \mathrm{ml}$. This figure corresponds well with the mean determined value for total serum copper but is about 6 per cent above the mean value for the indirectreacting fraction.

\section{Pregnancy}

Studies were made in 10 women. The results are presented in Table II. The total serum cop-

TABLE II

Pregnancy

(Third trimester)

\begin{tabular}{|c|c|c|c|c|c|}
\hline Patient & $\begin{array}{c}\text { Total } \\
\text { serum } \\
\text { copper } \\
\mu \mathrm{g} / 100 \mathrm{ml} .\end{array}$ & $\begin{array}{c}\text { Direct- } \\
\text { reacting } \\
\text { copper } \\
\mu g / 100 \mathrm{ml} .\end{array}$ & $\begin{array}{c}\text { Indirect- } \\
\text { reacting } \\
\text { copper } \\
\mu \mathrm{g} / 100 \mathrm{ml} .\end{array}$ & $\begin{array}{c}\text { Cerulo- } \\
\text { plasmin } \\
m \mathrm{~g} . / 100 \mathrm{ml} .\end{array}$ & $\begin{array}{c}\text { Oxidase } \\
\text { activity } \\
\mu M O_{2} / m l . / h r\end{array}$ \\
\hline $\begin{array}{l}\text { F. K. } \\
\text { F. F. } \\
\text { A. G. } \\
\text { E. K. } \\
\text { S. L. } \\
\text { W. L. } \\
\text { K. W. } \\
\text { J. S. } \\
\text { S. B. } \\
\text { R. M. }\end{array}$ & $\begin{array}{l}267 \\
222 \\
297 \\
249 \\
273 \\
216 \\
223 \\
216 \\
288 \\
324\end{array}$ & $\begin{array}{l}51 \\
31 \\
20 \\
17 \\
26 \\
37 \\
11 \\
20 \\
29 \\
49\end{array}$ & $\begin{array}{l}216 \\
191 \\
277 \\
232 \\
247 \\
179 \\
212 \\
196 \\
259 \\
275\end{array}$ & $\begin{array}{r}86 \\
68 \\
107 \\
83 \\
92 \\
62 \\
80 \\
68 \\
94 \\
99\end{array}$ & \begin{tabular}{r|}
10.1 \\
10.7 \\
12.6 \\
11.7 \\
9.3 \\
6.6 \\
8.2 \\
6.1 \\
9.1 \\
11.5
\end{tabular} \\
\hline $\begin{array}{l}\text { Mean } \\
\pm S . D . \\
\text { Range }\end{array}$ & $\begin{array}{c}257 \\
\pm 38 \\
216-297\end{array}$ & $\begin{array}{c}29 \\
\pm 13 \\
11-51\end{array}$ & $\begin{array}{c}228 \\
\pm 35 \\
179-277\end{array}$ & $\begin{array}{c}84 \\
\pm 15 \\
62-107\end{array}$ & $\begin{array}{c}9.6 \\
\pm 2.2 \\
6.6-12.6\end{array}$ \\
\hline
\end{tabular}


TABLE III

Infection

\begin{tabular}{|c|c|c|c|c|c|c|}
\hline Patient & Disease & $\begin{array}{c}\text { Total } \\
\text { serum } \\
\text { copper } \\
\mu \mathrm{g} / 100 \mathrm{ml} .\end{array}$ & $\begin{array}{c}\text { Direct- } \\
\text { reacting } \\
\text { copper } \\
\mu \mathrm{g} / 100 \mathrm{ml} .\end{array}$ & $\begin{array}{c}\text { Indirect- } \\
\text { reacting } \\
\text { copper } \\
\mu \mathrm{g} / 100 \mathrm{ml} .\end{array}$ & $\underset{\substack{\text { Cerulo- } \\
\text { plasmin } \\
\mathbf{m g} . / 100 \mathrm{ml} .}}{.}$ & $\begin{array}{c}\text { Oxidase } \\
\text { activity } \\
\mu M \mathrm{O}_{2} / m l^{\prime} / \mathrm{hr} .\end{array}$ \\
\hline $\begin{array}{l}\text { R.P. } \\
\text { E. C. } \\
\text { W. H. } \\
\text { E. W. } \\
\text { I. H. } \\
\text { E. M. } \\
\text { B. K. }\end{array}$ & $\begin{array}{l}\text { Tuberculosis } \\
\text { Tuberculosis } \\
\text { Tuberculosis } \\
\text { Pneumonia } \\
\text { Pneumonia } \\
\text { Staph. abscess* } \\
\text { Sinusitis }\end{array}$ & $\begin{array}{l}178 \\
172 \\
154 \\
200 \\
219 \\
219 \\
203\end{array}$ & $\begin{array}{r}26 \\
11 \\
6 \\
23 \\
17 \\
26 \\
11\end{array}$ & $\begin{array}{l}152 \\
161 \\
148 \\
177 \\
202 \\
193 \\
192\end{array}$ & $\begin{array}{l}63 \\
60 \\
60 \\
72 \\
75 \\
83 \\
61\end{array}$ & $\begin{array}{l}8.1 \\
8.7 \\
7.2 \\
7.7 \\
9.3 \\
8.0 \\
7.6\end{array}$ \\
\hline $\begin{array}{l}\text { Mean } \\
\text { Range }\end{array}$ & & $\begin{array}{c}192 \\
154-219\end{array}$ & $\begin{array}{c}17 \\
6-26\end{array}$ & $\begin{array}{c}175 \\
148-202\end{array}$ & $\begin{array}{c}68 \\
60-83\end{array}$ & $\begin{array}{c}8.1 \\
7.2-9.3\end{array}$ \\
\hline
\end{tabular}

* Complicating acute leukemia.

per, direct-reacting serum copper, ceruloplasmin and oxidase activity were all greatly increased above normal. The mean total serum copper was increased 138 per cent, the mean direct-reacting 480 per cent, the mean ceruloplasmin 147 per cent, and the mean oxidase activity 146 per cent above the normal mean values. The amount of copper accounted for in ceruloplasmin, on a basis of 0.32 per cent copper, was $269 \mu \mathrm{g}$ per $100 \mathrm{ml}$. This value is 4.7 per cent greater than the determined total serum copper and greater than the mean indirect-reacting copper by 18 per cent.

\section{Infection}

The values observed in seven patients with infection (Table III) were similar to those in pregnancy although the changes were not as great. The mean total serum copper was increased 78 per cent above the normal mean, the direct-reacting copper 240 per cent, the ceruloplasmin 100 per cent, and the oxidase activity 108 per cent. The amount of copper accounted for by cerulo- plasmin was $218 \mu \mathrm{g}$ per cent. Again, this was greater (12 per cent) than the determined total serum copper and indirect-reacting copper (24 per cent). In the case of E. M., the copper present in ceruloplasmin by calculation was 22 per cent greater than the determined total plasma copper and 39 per cent greater than the indirect-reacting value. It is of interest that this patient had hyperglobulinemia with 5.6 grams of total globulin per $100 \mathrm{ml}$. of serum.

\section{Nephrotic syndrome}

The results in seven patients with the nephrotic syndrome are presented in Table IV. In only four of the nine patients was hypocupremia present. The mean value for total serum copper for the group was $86 \mu \mathrm{g}$ per $100 \mathrm{ml}$. The ceruloplasmin level was increased above the upper limit of normal in two patients (C. E. and H. B.), was within the normal range in two patients (G. H. and R. P.), and was below the lower limit of normal in the five remaining patients. It is of

TABLE IV

Nephrotic syndrome

\begin{tabular}{|c|c|c|c|c|c|}
\hline Patient & $\begin{array}{c}\text { Total } \\
\text { serum } \\
\text { copper } \\
\mu g / 100 \mathrm{ml} .\end{array}$ & $\begin{array}{c}\text { Direct- } \\
\text { reacting } \\
\text { copper } \\
\mu \mathrm{g} / 100 \mathrm{ml} .\end{array}$ & $\begin{array}{l}\text { Indirect- } \\
\text { reacting } \\
\text { copper } \\
\mu \mathrm{g} / 100 \mathrm{ml} .\end{array}$ & $\underset{\substack{\text { Cerulo- } \\
\text { plasmin } \\
\mathbf{m g} . / 100 \mathrm{ml} .}}{.}$ & $\begin{array}{c}\text { Oxidase } \\
\text { activity } \\
\mu \mathrm{MO} \mathrm{O}_{2} / m l . / h r .\end{array}$ \\
\hline \multirow{3}{*}{$\begin{array}{l}\text { C. E. } \\
\text { H. B. } \\
\text { G. H. } \\
\text { R. P. } \\
\text { L. L. } \\
\text { C. S. } \\
\text { S. C. } \\
\text { W. W. } \\
\text { H. A. }\end{array}$} & \multirow{3}{*}{$\begin{array}{r}129 \\
126 \\
102 \\
96 \\
95 \\
72 \\
67 \\
48 \\
36\end{array}$} & $\begin{array}{r}8 \\
17\end{array}$ & $\begin{array}{l}121 \\
109\end{array}$ & \multirow{3}{*}{$\begin{array}{l}54 \\
46 \\
29 \\
29 \\
26 \\
21 \\
12 \\
13 \\
12\end{array}$} & $\begin{array}{l}6.2 \\
4.6\end{array}$ \\
\hline & & 26 & 70 & & 2.5 \\
\hline & & 26 & 46 & & 2.3 \\
\hline
\end{tabular}


TABLE $V$

Protein, copper, and ceruloplasmin in the urine of four patients with the nephrotic syndrome

\begin{tabular}{cccc}
\hline \hline Patient & $\begin{array}{c}\text { Protein } \\
\text { gm./24 hrs. }\end{array}$ & $\begin{array}{c}\text { Copper } \\
\mu \mathrm{mg} / 24 \text { hrs. }\end{array}$ & $\begin{array}{c}\text { Ceruloplasmin } \\
\text { mg./24 hrs. }\end{array}$ \\
\hline Normal & $<0.8$ & $0-26$ & 0 \\
\hline R. P. & 4 & 205 & 50 \\
C. E. & 5 & 239 & 55 \\
C. S. & 11 & 246 & 46 \\
H. B. & 18 & 410 & 75 \\
\hline
\end{tabular}

interest that in three of the patients (S. C., W. W., and H. A.) the ceruloplasmin values were as low as those seen in hepatolenticular degeneration. Direct-reacting copper was measured in only four patients. In two of these (R. P. and $\mathrm{C}$. S.) the values were above the upper limit of normal.

From Table IV it is apparent that there was high degree of correlation between the total serum copper level and the ceruloplasmin and oxidase activity.

The excretion of protein, copper, and ceruloplasmin in the urine was measured in four patients (Table V). From 46 to $75 \mathrm{mg}$. of ceruloplasmin were excreted in the urine per 24 hours. ${ }^{8}$

\section{Hepatolenticular degeneration}

The results in 14 patients with hepatolenticular degeneration are shown in Table VI. The serum

6 Oxidase activity was demonstrable in the urine of these patients and was not detectable in normal urine. copper level was less than $68 \mu \mathrm{g}$ per cent, the lower limit of normal (23), in 11 of the 14 patients. In the remaining three patients (D. C., A. S., and P. C.) the serum copper levels were 86,100 , and $77 \mu \mathrm{g}$ per $100 \mathrm{ml}$., respectively. In all of the patients the ceruloplasmin concentration was less than the lower limit of normal (Table I). The direct-reacting copper was increased above normal in 4 of the 5 patients on whom this was measured. In all five of the patients studied, the indirect-reacting fraction was reduced below normal. The oxidase activity was greatly reduced in all four of the patients on whom this determination was performed.

The ceruloplasmin concentration in the different patients ranged between 2 and $19 \mathrm{mg}$. per 100 $\mathrm{ml}$. Between the range of 2 to $11 \mathrm{mg}$. per $100 \mathrm{ml}$. of ceruloplasmin, there was no correlation with the total serum copper level which ranged from 35 to $60 \mu \mathrm{g}$ per $100 \mathrm{ml}$. In the three patients with ceruloplasmin levels greater than $11 \mathrm{mg}$. per $100 \mathrm{ml}$., the serum copper levels were greater $(77,100$, and $86 \mu \mathrm{g}$ per $100 \mathrm{ml}$.) than in those with the lower ceruloplasmin levels. There was good correlation between the indirect-reacting copper and the ceruloplasmin level in the few patients studied.

The clinical data on the patients with Wilson's disease are summarized briefly in Table VII. As is evident in this table and in Table VI, there was no obvious correlation between the ceruloplasmin concentration in the serum and the duration or

TABLE VI

Hepatolenticular degeneration

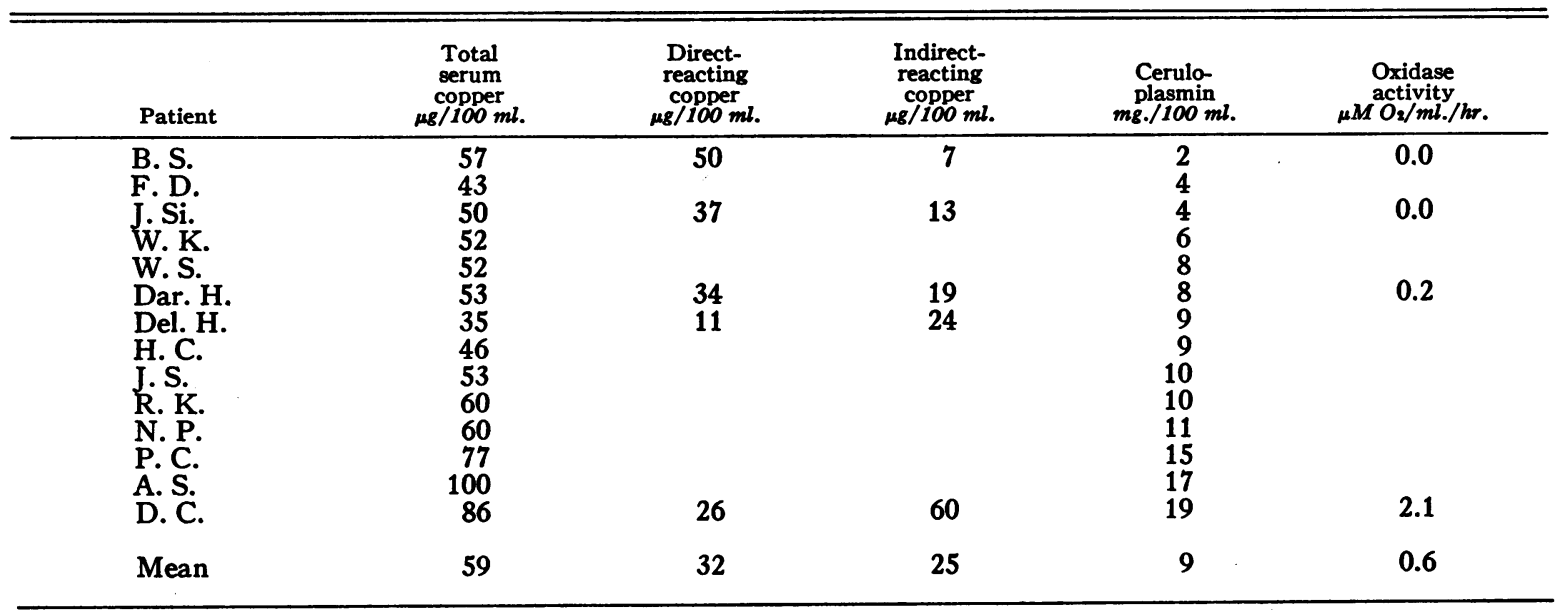


TABLE VII

Clinical data on cases of hepatolenticular degeneration

\begin{tabular}{|c|c|c|c|c|c|c|c|c|c|c|}
\hline \multirow[b]{2}{*}{ Patient } & \multirow{2}{*}{$\begin{array}{c}\text { Age } \\
\text { years }\end{array}$} & \multirow[b]{2}{*}{ Sex } & \multirow{2}{*}{$\begin{array}{c}\text { Duration } \\
\text { symptoms } \\
\text { years }\end{array}$} & \multirow{2}{*}{$\underset{\text { rings }}{\text { K-F }}$} & \multirow{2}{*}{ 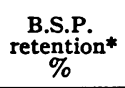 } & \multicolumn{3}{|c|}{ Neurologic manifestations } & \multirow{2}{*}{$\begin{array}{l}\text { Hyper- } \\
\text { cupriuria }\end{array}$} & \multirow{2}{*}{$\begin{array}{l}\text { Hyper- } \\
\text { amino- } \\
\text { aciduria }\end{array}$} \\
\hline & & & & & & Dysarthria & Tremor & Spasticity & & \\
\hline $\begin{array}{l}\text { B. S. } \\
\text { F. D. } \\
\text { J. Si. } \\
\text { W. K. } \\
\text { W. S. } \\
\text { Dar. H. } \\
\text { Del. H. } \\
\text { H. C. } \\
\text { J. S. } \\
\text { R. K. } \\
\text { N. P. } \\
\text { P. C. } \\
\text { A. S. } \\
\text { D. C. }\end{array}$ & $\begin{array}{l}18 \\
23 \\
35 \\
31 \\
29 \\
11 \\
15 \\
17 \\
30 \\
22 \\
31 \\
14 \\
19 \\
29\end{array}$ & $\begin{array}{l}\mathbf{M} \\
\mathbf{M} \\
\mathbf{M} \\
\mathbf{M} \\
\mathbf{M} \\
\mathbf{F} \\
\mathbf{M} \\
\mathbf{M} \\
\mathbf{F} \\
\mathbf{M} \\
\mathbf{F} \\
\mathbf{M} \\
\mathbf{M} \\
\mathbf{F}\end{array}$ & $\begin{array}{r}2 \\
4 \\
12 \\
5 \\
3 \\
0 \\
6 \\
6 \\
4 \\
13 \\
0 \\
\end{array}$ & $\begin{array}{l}+ \\
+ \\
+ \\
+ \\
+ \\
+ \\
+ \\
+ \\
+ \\
+ \\
+ \\
0 \\
+ \\
+\end{array}$ & $\begin{array}{r}5 \\
11 \\
10 \\
5 \\
5 \\
26 \\
28 \\
\\
2 \\
8 \\
13 \\
\\
20 \\
32\end{array}$ & $\begin{array}{l}+ \\
+ \\
+ \\
+ \\
+ \\
0 \\
+ \\
0 \\
+ \\
+ \\
0 \\
+ \\
0 \\
+\end{array}$ & $\begin{array}{l}+ \\
+ \\
+ \\
+ \\
+ \\
0 \\
+ \\
0 \\
+ \\
+ \\
+ \\
+ \\
0 \\
+\end{array}$ & $\begin{array}{l}0 \\
0 \\
+ \\
0 \\
0 \\
0 \\
+ \\
0 \\
+ \\
+ \\
0 \\
0 \\
0 \\
+\end{array}$ & $\begin{array}{l}+ \\
+ \\
+ \\
+ \\
+ \\
+ \\
+ \\
+ \\
+ \\
+ \\
+ \\
+ \\
+\end{array}$ & $\begin{array}{l}+ \\
+ \\
+ \\
0 \\
+ \\
+ \\
+ \\
+ \\
0 \\
+\end{array}$ \\
\hline
\end{tabular}

* Forty-five minutes following the injection of $5 \mathrm{mg}$. per $\mathrm{Kg}$.

severity of the clinical manifestations in this very small series of patients. Patient D. C. with the highest ceruloplasmin concentration has been observed to have clinical signs of the disease for at least four years. Her liver function is abnormal and there is well advanced neurologic disease (13). Patient B. S. with the lowest ceruloplasmin concentration has shown clinical signs for only two years, all of the liver function tests are essentially normal, and he has only a moderate degree of dysarthria and minimal tremor of the left arm. Patient Del. H. with a ceruloplasmin level of $9 \mathrm{mg}$. per $100 \mathrm{ml}$. died with severe liver impairment and neurologic disease one month after the ceruloplasmin determination (13). It may be added that there was no correlation between the concentration of ceruloplasmin and the age of the patient, the duration of clinical symptoms or signs, the presence or absence of neurologic disease, or the degree of liver function impairment as determined by bromsulfalein retention.

The urine of three of the patients (D. C., Dar. H., and F. D.) was examined for ceruloplasmin by the immunologic technique and none or, at most, traces were found even though all three of the patients were excreting abnormally large quantities of copper in the urine.

\section{Neurologic disorders other than hepatolenticular degeneration}

In order to learn whether or not a decrease in ceruloplasmin occurs in neurologic conditions other than Wilson's disease, determinations were performed on four patients with the Parkinsonian syndrome, three patients with schizophrenia, two patients with multiple sclerosis, one with a familial tremor, one with myasthenia gravis, and two with Huntington's chorea. The results are presented in Table VIII.

In none of the patients studied was there a significant decrease below the normal in total serum copper, indirect-reacting copper, or ceruloplasmin. In one patient with schizophrenia (D. K.) there was an increase in the direct-reacting fraction and a slightly low indirect-reacting copper. The oxidase activity was distinctly reduced. In two other patients with neurologic disease (J. P. and W. B.) the oxidase activity was reduced even though the ceruloplasmin levels were normal. In the patient with myasthenia gravis (M. H.) the ceruloplasmin level was at the lower limits of normal. We do not regard these slight deviations as being of any significance.

\section{Ceruloplasmin in tissues}

The concentration of ceruloplasmin was measured in several tissues of one patient (Del. H.) with hepatolenticular degeneration and one control subject (K. D., traumatic death). The concentration in the kidney was measured in one additional control subject (H. C., diabetes mellitus). The results are presented in Table IX.

Small quantities of ceruloplasmin were detected in the liver and kidney of the control subjects, and none was detected in the spleen, basal ganglion, cerebellum, bile, or erythrocytes. Even in the 
TABLE VIII

Neurologic disorders other than Wilson's disease

\begin{tabular}{|c|c|c|c|c|c|c|}
\hline Patient & Condition & $\begin{array}{c}\text { Total } \\
\text { serum } \\
\text { copper } \\
\mu g / 100 \mathrm{ml} .\end{array}$ & $\begin{array}{c}\text { Direct- } \\
\text { reacting } \\
\text { copper } \\
\mu \mathrm{g} / 100 \mathrm{ml} .\end{array}$ & $\begin{array}{c}\text { Indirect- } \\
\text { reacting } \\
\text { copper } \\
\mu \mathrm{g} / 100 \mathrm{ml} .\end{array}$ & $\underset{\substack{\text { Cerulo- } \\
\text { plasmin } \\
m \mathrm{~g} . / 100 \mathrm{ml} .}}{.}$ & $\begin{array}{c}\text { Oxidase } \\
\text { activity } \\
\mu M O_{2} / m b . / h r .\end{array}$ \\
\hline $\begin{array}{l}\text { A. L. } \\
\text { M. R. } \\
\text { J. Z. } \\
\text { J. P. } \\
\text { E. C. } \\
\text { J. H. } \\
\text { R. P. } \\
\text { K. K. } \\
\text { D. K. } \\
\text { W. B. } \\
\text { M. H. } \\
\text { T. T. } \\
\text { A. D. }\end{array}$ & $\begin{array}{l}\text { Parkinsonian syndrome } \\
\text { Parkinsonian syndrome } \\
\text { Parkinsonian syndrome } \\
\text { Parkinsonian syndrome } \\
\text { Multiple sclerosis } \\
\text { Multiple sclerosis } \\
\text { Schizophrenia } \\
\text { Schizophrenia } \\
\text { Schizophrenia } \\
\text { Familial tremor } \\
\text { Myasthenia gravis } \\
\text { Huntington's chorea } \\
\text { Huntington's chorea }\end{array}$ & $\begin{array}{r}174 \\
144 \\
169 \\
104 \\
129 \\
156 \\
150 \\
123 \\
93 \\
107 \\
125 \\
141 \\
111\end{array}$ & $\begin{array}{r}3 \\
0 \\
20 \\
9 \\
0 \\
9 \\
9 \\
9 \\
26 \\
6 \\
0\end{array}$ & $\begin{array}{r}171 \\
144 \\
149 \\
95 \\
129 \\
147 \\
141 \\
114 \\
67 \\
101 \\
125\end{array}$ & $\begin{array}{l}75 \\
51 \\
59 \\
33 \\
59 \\
78 \\
58 \\
38 \\
32 \\
31 \\
26 \\
31 \\
28\end{array}$ & $\begin{array}{l}6.4 \\
5.7 \\
6.3 \\
2.0 \\
5.3 \\
6.9 \\
6.0 \\
4.2 \\
1.5 \\
2.5 \\
4.7\end{array}$ \\
\hline
\end{tabular}

liver and kidney the copper in ceruloplasmin accounted for only a small fraction of the total copper present. In the liver and kidney of the patient with Wilson's disease the total copper was increased as compared with that found in the "controls" and almost none of this was in the form of ceruloplasmin.

\section{DISCUSSION}

The data presented demonstrate a high degree of correlation between the total plasma copper level and the concentration of ceruloplasmin (Figure 1 ), between the indirect-reacting fraction of plasma copper and ceruloplasmin (Figure 2), and between the serum oxidase activity and ceruloplasmin concentration (Figure 3 ) in normal human subjects, in pregnant women and in patients with infections, the nephrotic syndrome and certain neurologic disorders other than Wilson's disease. The mean values for ceruloplasmin in normal subjects and in patients with Wilson's disease are in excellent agreement with those obtained by Scheinberg and Gitlin (15). However, the mean values of $84 \mathrm{mg}$. per $100 \mathrm{ml}$. for ceruloplasmin and $29 \mu \mathrm{g}$ per $100 \mathrm{ml}$. for the direct-reacting copper in pregnant women in the last tri-

TABLE IX

Ceruloplasmin in tissues

\begin{tabular}{|c|c|c|c|c|c|}
\hline Tissue & Condition & Subject & $\begin{array}{c}\text { Copper } \\
\mu g / g m . *\end{array}$ & $\begin{array}{c}\text { Cerulo- } \\
\text { plasmin } \\
\mu \& / g m . *\end{array}$ & $\begin{array}{c}\text { Proportion of } \\
\text { total copper } \\
\text { in ceruloplasmin } \\
\%\end{array}$ \\
\hline Liver $\mu g / g m$. & $\begin{array}{l}\text { Control } \\
\text { W. D. }\end{array}$ & $\begin{array}{l}\text { K. D. } \\
\text { Del. H. }\end{array}$ & $\begin{array}{r}3.9 \\
98.4\end{array}$ & $\begin{array}{l}55 \\
20\end{array}$ & $\begin{array}{l}4.5 \\
0.1\end{array}$ \\
\hline Spleen $\mu g / g m$. & $\begin{array}{l}\text { Control } \\
\text { W. D. }\end{array}$ & $\begin{array}{l}\text { K. D. } \\
\text { Del. H. }\end{array}$ & $\begin{array}{l}0.7 \\
1.5\end{array}$ & $\begin{array}{l}\mathbf{0} \\
\mathbf{0}\end{array}$ & $\begin{array}{l}\mathbf{0} \\
\mathbf{0}\end{array}$ \\
\hline Kidney $\mu g / g m$. & $\begin{array}{l}\text { Control } \\
\text { Control } \\
\text { W. D. }\end{array}$ & $\begin{array}{l}\text { K. D. } \\
\text { H. C. } \\
\text { Del. H. }\end{array}$ & $\begin{array}{l}1.9 \\
4.1 \\
8.7\end{array}$ & $\begin{array}{l}73 \\
50 \\
12\end{array}$ & $\begin{array}{r}12.1 \\
3.9 \\
0.4\end{array}$ \\
\hline Basal ganglion $\mu \mathrm{g} / \mathrm{gm}$. & $\begin{array}{l}\text { Control } \\
\text { W. D. }\end{array}$ & $\begin{array}{l}\text { K. D. } \\
\text { Del. H. }\end{array}$ & $\begin{array}{r}6.0 \\
56.4\end{array}$ & $\begin{array}{l}0 \\
0\end{array}$ & $\begin{array}{l}\mathbf{0} \\
\mathbf{0}\end{array}$ \\
\hline Cerebellum $\mu g / g m$. & W. D. & Del. H. & 67.4 & $\mathbf{0}$ & 0 \\
\hline Bile $\mu \mathrm{g} / 100 \mathrm{ml}$. & W. D. & Del. H. & 19.0 & $\mathbf{0}$ & $\mathbf{0}$ \\
\hline Erythrocytes $\mu \mathrm{g} / 100 \mathrm{ml}$. & Control & H. M. & 115.0 & $\mathbf{0}$ & $\mathbf{0}$ \\
\hline
\end{tabular}

* Wet tissue.

† W. D. refers to Wilson's Disease. 
mester are higher than the mean values of $56 \mathrm{mg}$. and $10.6 \mu \mathrm{g}$ found by Scheinberg, Cook, and Murphy (11) in women at the time of delivery.

In general, the values for ceruloplasmin copper, calculated on the basis of 0.32 per cent copper in ceruloplasmin, were higher than the corresponding indirect-copper values. In some instances, these were even higher than the total copper values. This discrepancy was greater in sera with high copper concentrations than in sera with low or normal concentrations of copper. In patient E. M. (Table III) with hyperglobulinemia, the

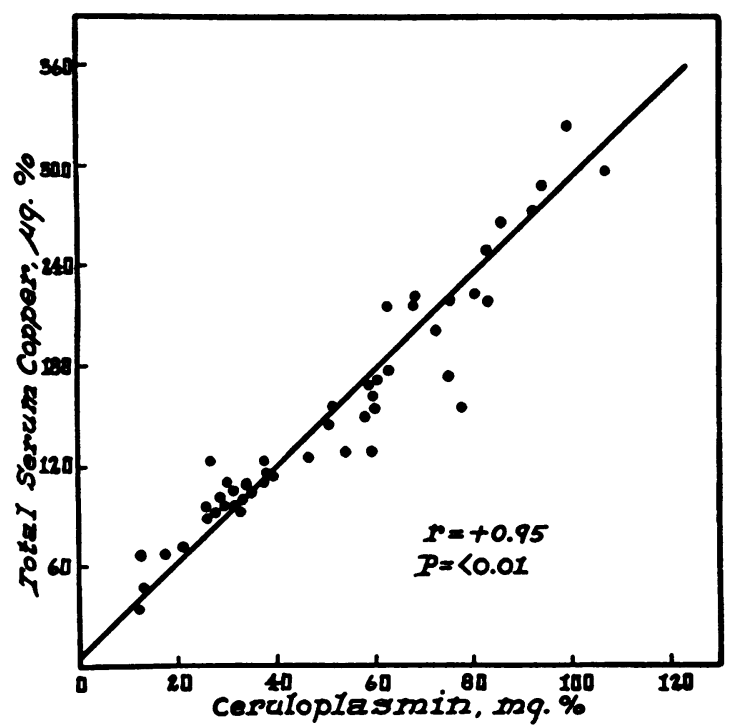

Fig. 1. The Correlation between the Total Serum Copper and Ceruloplasmin

All of the values for normal subjects, pregnant women, and patients with infection, the nephrotic syndrome and neurologic disease other than hepatolenticular degeneration have been plotted. The diagonal line was plotted by the method of least squares. $\mathrm{r}$ refers to the correlation coefficient. $\mathrm{P}$ refers to the probability of such a correlation occurring by chance.

calculated ceruloplasmin copper was 22 per cent greater than the total serum copper. These results suggest that the antiserum used contained antibodies to proteins other than ceruloplasmin. In order to test this possibility the serum of A. L. (Table VIII) with a total copper of $174 \mu \mathrm{g}$ per $100 \mathrm{ml}$. and a calculated ceruloplasmin copper of $240 \mu \mathrm{g}$ per $100 \mathrm{ml}$. was studied by the Oudin agar diffusion technique. Only a single zone was found. Although this does not entirely eliminate the possibility that antibodies to proteins other

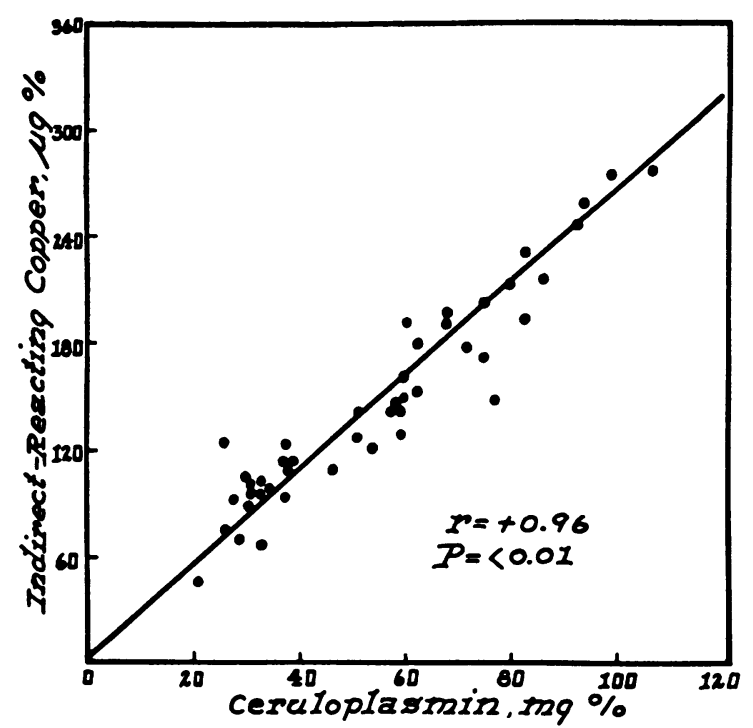

Fig. 2. The Correlation between the IndirectReacting Fraction of Serum Copper and CeruloPLASMIN

For explanation see legend for Figure 1.

than ceruloplasmin were present, it makes this explanation less plausible. An alternative explanation, which is entirely without experimental support, is that there may be in serum a copper

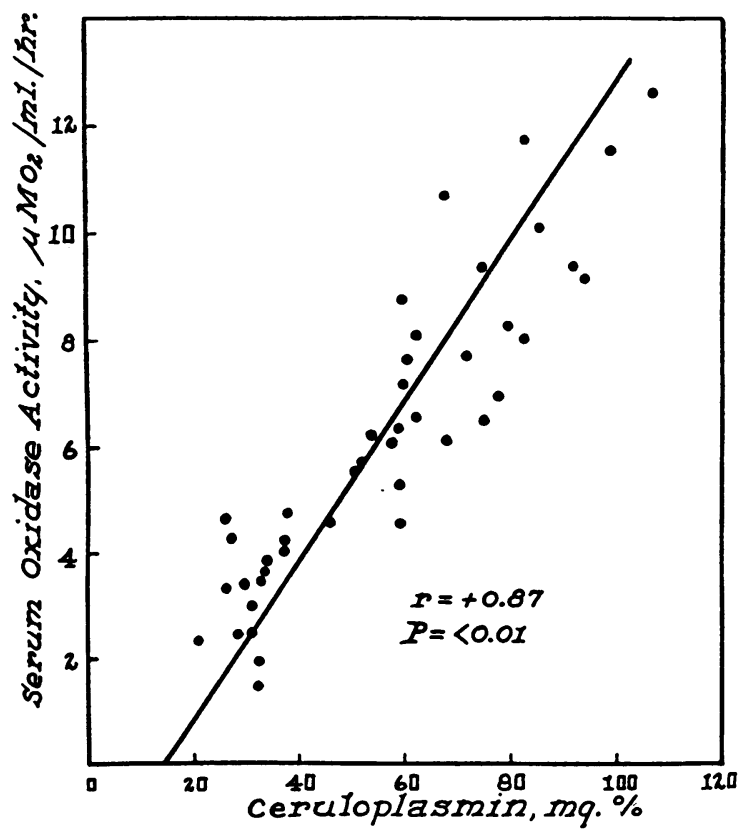

Fig. 3. The Correlation between the Serum Oxidase ACtivity aNd Ceruloplasmin

For explanation see legend for Figure 1. 
protein or proteins with copper concentrations of less than 0.32 per cent which are closely related to ceruloplasmin and which react with this substance. If such were the case, it might explain why there is a poor correlation between the immunologically determined ceruloplasmin concentration and the clinical manifestations of Wilson's disease.

The significance and importance of low levels of ceruloplasmin need to be elucidated. Scheinberg and Gitlin (15) have advanced the hypothesis that Wilson's disease is due to a congenital deficiency of ceruloplasmin. This hypothesis is indeed attractive and has been favored by Bearn (24) as well as by ourselves (13). If hypoceruloplasminemia is in itself of pathogenetic significance, it might be expected that there would be a correlation between the degree of deficiency of ceruloplasmin in the serum and the duration or severity of the clinical manifestations of Wilson's disease. In our small group of patients the ceruloplasmin levels ranged from 2 to $19 \mathrm{mg}$. per $100 \mathrm{ml}$. and no such correlation was observed. Furthermore, ceruloplasmin levels as low as those found in Wilson's disease were observed in three patients with the nephrotic syndrome. Admittedly, the hypoceruloplasminemia in the cases of nephrosis was probably of a much shorter duration than in the patients with Wilson's disease. Finally, one additional observation seems worthy of mention. In 1951 an apparently normal and healthy 28-year-old male physician was found to have a plasma copper level of $68 \mu \mathrm{g}$ per $100 \mathrm{ml}$. This value was the lowest we had found in a total of 228 normal subjects $(14,23)$. Re-examination of the serum of this individual in 1954 and again in 1955 revealed a plasma copper level of 68 and $69 \mu \mathrm{g}$ per $100 \mathrm{ml}$. On the last examination the direct-reacting copper was $26 \mu \mathrm{g}$ per 100 $\mathrm{ml}$., the indirect-reacting copper was $43 \mu \mathrm{g}$ per $100 \mathrm{ml}$., ceruloplasmin $20.3 \mathrm{mg}$. per $100 \mathrm{ml}$., and oxidase activity $2.4 \mu \mathrm{M} \mathrm{O}_{2}$ per $\mathrm{ml}$. per hr. Thus, this individual apparently has had a ceruloplasmin level of about $20 \mathrm{mg}$. per $100 \mathrm{ml}$. for at least four years. There is no familial history of Wilson's disease and physical and laboratory examinations, including liver function tests and urine copper analysis, are unremarkable except for palpable liver and a persistent unexplained neutrophilic leukocytosis. Although this individual is not entirely normal, it seems most unlikely that he has hepatolenticular degeneration. Yet, for a period of at least four years, he has had a ceruloplasmin concentration only about $1 \mathrm{mg}$. per 100 ml. higher than patient D. C. (Table VI) with severe disease.

The low levels of ceruloplasmin found in Wilson's disease might be explained by either failure to form or increased destruction of this enzyme. In the nephrotic syndrome loss of this protein in the urine seems to be the most important factor. In a previous publication from this laboratory (14) it was pointed out that patients with the nephrotic syndrome excrete between 100 and $600 \mu \mathrm{g}$ of copper per 24 hours in the urine. The degree of cupriuria was found to be correlated with the degree of proteinuria and it was postulated that ceruloplasmin was being excreted by the kidney under these circumstances. Our present observation that 46 to $75 \mathrm{mg}$. of ceruloplasmin were excreted daily in the urine of five patients with the nephrotic syndrome gives support to this suggestion. In these cases the ceruloplasmin accounted for 60 to 80 per cent of the copper excreted in the urine per day. Since the normal serum pool of ceruloplasmin is approximately one gram, these patients were excreting about onetwentieth of the normal serum pool of this protein in the urine per day. This represents an appreciable loss of ceruloplasmin from the body by an abnormal route, since ceruloplasmin is not found in the urine of normal subjects in detectable quantities. Apparently, in those cases of the nephrotic syndrome in which hypocupremia and hypoceruloplasminemia were found, the rate of synthesis of ceruloplasmin was not great enough to maintain normal levels of ceruloplasmin.

The results of our tissue analyses for ceruloplasmin are of interest but difficult to interpret. Both in the control subjects and in the case of Wilson's disease ceruloplasmin could be demonstrated only in liver and in kidney. The finding of ceruloplasmin in the kidney in concentrations equal to or higher than in the liver was unexpected. Its absence in tissues, such as basal ganglion, cerebellum and erythrocytes, which normally contain greater quantities of copper than the kidney, is noteworthy. It is also interesting that the proportion of the copper in the liver and kidney of the case of Wilson's disease which could 
be accounted for as ceruloplasmin was extremely small.

\section{SUMMARY}

1. Total serum copper, direct-reacting copper, indirect-reacting copper, ceruloplasmin, and oxidase activity were measured in the sera of 10 normal subjects. The mean values ( \pm one standard deviation) observed were as follows: total serum copper, $108 \pm 9 \mu \mathrm{g}$ per $100 \mathrm{ml}$; directreacting copper, $5 \pm 6 \mu \mathrm{g}$ per $100 \mathrm{ml}$.; indirectreacting copper, $103 \pm 11 \mu \mathrm{g}$ per $100 \mathrm{ml}$.; ceruloplasmin, $34 \pm 4 \mathrm{mg}$. per $100 \mathrm{ml}$. ; oxidase activity, $3.9 \pm 0.7 \mu \mathrm{M} \mathrm{O}_{2}$ per ml. per hr.

2. Corresponding values in 10 pregnant women in the last trimester of pregnancy were as follows: total serum copper, $257 \pm 38 \mu \mathrm{g}$ per $100 \mathrm{ml}$.; direct-reacting copper, $29 \pm 13 \mu \mathrm{g}$ per $100 \mathrm{ml}$; indirect-reacting copper $228 \pm 35 \mu \mathrm{g}$ per $100 \mathrm{ml}$; ceruloplasmin, $84 \pm 15 \mathrm{mg}$. per $100 \mathrm{ml}$; oxidase activity, $9.6 \pm 2.2 \mu \mathrm{M} \mathrm{O}_{2}$ per $\mathrm{ml}$. per hr. A high degree of correlation was observed between the total serum copper, indirect-reacting copper, ceruloplasmin, and oxidase activity.

3. Mean values in seven patients with chronic infections were as follows: total serum copper, $192 \mu \mathrm{g}$ per $100 \mathrm{ml}$; d direct-reacting copper, $17 \mu \mathrm{g}$ per $100 \mathrm{ml}$; indirect-reacting copper, $175 \mu \mathrm{g}$ per $100 \mathrm{ml}$; ; ceruloplasmin, $68 \mathrm{mg}$. per $100 \mathrm{ml}$.; oxidase activity, 8.1 $\mu \mathrm{M} \mathrm{O}_{2}$ per ml. per hr. As in the pregnant women, a high degree of correlation was observed between the total serum copper, indirect-reacting copper, ceruloplasmin, and oxidase activity.

4. In nine patients with the nephrotic syndrome, the total serum copper values ranged from $129 \mu \mathrm{g}$ per $100 \mathrm{ml}$. to as low as $36 \mu \mathrm{g}$ per $100 \mathrm{ml}$. In those in whom there was hypocupremia, a corresponding reduction in the ceruloplasmin concentration was present. Four of these patients were found to excrete between 46 and $75 \mathrm{mg}$. of ceruloplasmin per 24 hours in the urine.

5. In 14 patients with hepatolenticular degeneration, the total serum copper values ranged between 35 and $100 \mu \mathrm{g}$ per $100 \mathrm{ml}$. Ceruloplasmin values were below normal, ranging between 2 and $19 \mathrm{mg}$. per $100 \mathrm{ml}$. In general, there was an increase in the direct-reacting fraction of copper and a decrease in the oxidase activity. There was little correlation between the total serum copper values and the ceruloplasmin values. In five patients there was good correlation between the indirect-reacting copper and ceruloplasmin. No correlation was found between the ceruloplasmin level and the duration or severity of the clinical manifestations of the disease. Significant quantities of ceruloplasmin were not found in the urine.

6. In neurologic diseases other than hepatolenticular degeneration the total serum copper level was either normal or increased and there was no decrease in the quantity of ceruloplasmin in the serum.

7. Ceruloplasmin was found in small quantities in the liver of one "control" subject and in the kidney of two "control" subjects. Ceruloplasmin was not found in brain, spleen, bile, or erythrocytes of the "control" subjects or of the patient with Wilson's disease. Ceruloplasmin was found in the liver and kidney of one patient with Wilson's disease but this protein represented a much smaller proportion of the total copper demonstrable in these tissues than was the case in the control subjects.

8. The copper protein in normal erythrocytes was found to be immunologically distinct from ceruloplasmin.

\section{ACKNOWLEDGMENTS}

We are indebted to Dr. F. F. Johnson and Dr. J. H. Hink, Jr. of the Cutter Laboratories, Berkeley, California, for preparing several batches of ceruloplasmin for us. Miss Helen Ashenbrucker gave valuable technical assistance.

\section{REFERENCES}

1. Holmberg, C. G., and Laurell, C.-B., Investigations in serum copper. II. Isolation of the copper containing protein, and a description of some of its properties. Acta chem. Scandinav., 1948, 2, 550.

2. Holmberg, C. G., and Laurell, C.-B. Investigations in serum copper. III. Coeruloplasmin as an enzyme. Acta chem. Scandinav., 1951, 5, 476.

3. Holmberg, C. G., and Laurell, C.-B., Investigations in serum copper. IV. Effect of different anions on the enzymatic activity of coeruloplasmin. Acta chem. Scandinav., 1951, 5, 921.

4. Holmberg, C. G., and Laurell, C.-B., Investigations in serum copper. I. Nature of serum copper and its relation to the iron-binding protein in human serum. Acta. chem. Scandinav., 1947, 1, 944.

5. Gubler, C. J., Lahey, M. E., Cartwright, G. E., and Wintrobe, M. M., Studies on copper metabolism. 
IX. The transportation of copper in blood. J. Clin. Invest., 1953, 32, 405.

6. Bearn, A. G., and Kunkel, H. G., Localization of $\mathrm{Cu}^{\mathrm{e}}$ in serum fractions following oral administration. An alteration in Wilson's disease. Proc. Soc. Exper. Biol. \& Med., 1954, 85, 44.

7. Cartwright, G. E., Copper metabolism in human subjects in Copper Metabolism. A Symposium on Animal, Plant and Soil Relationships, edited by McElroy, W. D., and Glass, B., Baltimore, The Johns Hopkins Press, 1950, pp. 274-314.

8. Lahey, M. E., Gubler, C. J., Cartwright, G. E., and Wintrobe, M. M., Studies on copper metabolism. VII. Blood copper in pregnancy and various pathologic states. J. Clin. Invest., 1953, 32, 329.

9. Cartwright, G. E., and Wintrobe, M. M., The anemia of infection. XVII. A review. Advances Int. Med., 1952, 5, 165.

10. Holmberg, C. G., and Laurell, C.-B., Oxidase reactions in human plasma caused by coeruloplasmin. Scandinav. J. Lab. \& Clin. Invest., 1951, 3, 103.

11. Scheinberg, I. H., Cook, C. D., and Murphy, J. A., The concentration of copper and ceruloplasmin in maternal and infant plasma at delivery. J. Clin. Invest., 1954, 33, 963.

12. Bearn, A. G., and Kunkel, H. G., Abnormalities of copper metabolism in Wilson's disease and their relationship to the aminoaciduria. J. Clin. Invest., 1954, 33, 400.

13. Cartwright, G. E., Hodges, R. E., Gubler, C. J., Mahoney, J. P., Daum, K., Wintrobe, M. M., and Bean, W. B., Studies on copper metabolism. XIII. Hepatolenticular degeneration. J. Clin. Invest., 1954, 33, 1487.

14. Cartwright, G. E., Gubler, C. J., and Wintrobe, M. M., Studies on copper metabolism. XI. Copper and iron metabolism in the nephrotic syndrome. J. Clin. Invest., 1954, 33, 685.

15. Scheinberg, I. H., and Gitlin, D., Deficiency of ceruloplasmin in patients with hepatolenticular degeneration (Wilson's disease). Science, 1952, 116, 484.

16. Warnock, C. G., Hepatolenticular degeneration (Wilson's disease). Ulster M. J., 1952, 21, 155.

17. Warnock, C. G., and Neill, D. W., Dimercaprol in the pre-neurological stage of Wilson's disease (hepatolenticular degeneration). J. Neurol., Neurosurg. \& Psychiat., 1954, 17, 70.

18. Lahey, M. E., Gubler, C. J., Chase, M. S., Cartwright, G. E., and Wintrobe, M. M., Studies on copper metabolism. II. Hematologic manifestations of copper deficiency in swine. Blood, 1952, 7, 1053.

19. Lipton, M. M., and Freund, J., The efficacy of the intracutaneous route of injection and the susceptibility of the Hartley strain of guinea pigs in experimental allergic encephalitis. J. Immunol., 1953, 70, 326.

20. Oudin, J., L'analyse immunochimique du sérum humain et de ses fractions. 1. Inventaire provisoire des constituants de la principale fraction de globulines. Ann. Inst. Pasteur, 1953, 85, 336.

21. Heidelberger, M., and MacPherson, C. F. C., Quantitative micro-estimation of antibodies in the sera of man and other animals. Science, 1943, 97, 405.

22. Heidelberger, M., and MacPherson, C. F. C., Correction. Science, 1943, 98, 63.

23. Lahey, M. E., Gubler, C. J., Cartwright, G. E., and Wintrobe, M. M., Studies on copper metabolism. VI. Blood copper in normal human subjects. J. Clin. Invest., 1953, 32, 322.

24. Bearn, A. G., Genetic and biochemical aspects of Wilson's disease. Am. J. Med., 1953, 15, 442. 